\title{
Epigenetic inactivation of the $C H F R$ gene in cervical cancer contributes to sensitivity to taxanes
}

\author{
KOUJI BANNO*, MEGUMI YANOKURA*, MAKIKO KAWAGUCHI, YOSHIKO KUWABARA, \\ JYUNKO AKIYOSHI, YUSUKE KOBAYASHI, TAKASHI IWATA, AKIRA HIRASAWA, TAKUMA FUJII, \\ NOBUYUKI SUSUMU, KASTUMI TSUKAZAKI and DAISUKE AOKI
}

Department of Obstetrics and Gynecology, Keio University School of Medicine, Tokyo 160-8582, Japan

Received May 24, 2007; Accepted July 13, 2007

\begin{abstract}
A relationship between inactivation of mitotic checkpoint genes and sensitivity of cancer cells to anticancer agents has been reported. We investigated the effect of epigenetic inactivation by aberrant hypermethylation of the mitotic checkpoint gene CHFR (checkpoint with forkhead and ring finger) on the sensitivity of cervical cancer cells to taxanes. Methylation-specific PCR (MSP) of cervical smears showed aberrant methylation of CHFR in $12.3 \%$ (2/14) of adenocarcinoma specimens. In contrast, aberrant DNA methylation was not detected in normal cervical cells or squamous cell carcinoma cells. Aberrant methylation of CHFR was also analyzed in 6 human cervical carcinomaderived cell lines and was observed in SKG-IIIb and HeLa cells. These cell lines showed high sensitivity to taxanes, but became taxane-resistant upon treatment with 5-azacytidine. Furthermore, suppression of CHFR expression in siRNAtransfected SKG-IIIa cells caused increased sensitivity to taxanes. In conclusion, aberrant methylation of the CHFR gene may be useful as a molecular marker for selection of therapy for patients with cervical adenocarcinoma with a poor prognosis, and may also suggest a new therapeutic strategy of targeting CHFR in cervical cancer. To our knowledge, this study is the first to examine epigenetic inactivation by aberrant hypermethylation of $C H F R$ in cervical cancer.
\end{abstract}

\section{Introduction}

Cervical cancer is the second most common cause of cancerrelated mortality in women worldwide: nearly 500,000

Correspondence to: Dr Kouji Banno, Department of Obstetrics and Gynecology, Keio University School of Medicine, Shinanomachi 35, Shinjuku-ku, Tokyo 160-8582, Japan

E-mail:kbanno@sc.itc.keio.ac.jp

${ }^{*}$ Contributed equally

Key words: CHFR, cervical cancer, DNA hypermethyltion, taxane, chemosensitivity women are diagnosed with cervical cancer each year and many die of the desease. In the United States, there were approximately 14,500 new cervical cancer cases and 4,800 cervical cancer deaths in $1997(1,2)$. Cervical cancer differs from most other common malignancies in that it is strongly associated with an infection agent, human papillomavirus (HPV). Most studies have focused on the E6 and E7 transforming proteins of oncogenic HPV types, since E6 and E7 interfere with the function of the tumor-suppressor proteins p53 and $\mathrm{Rb}$ via protein-protein interactions. By interfering with cell cycle control and DNA repair mechanisms, oncogenic HPVs appear to contribute indirectly to cervical tumorgenesis by promoting genetic instability and the accumulation of mutations in HPV-infected cells $(3,4)$.

In addition to p53 and RB, p16INK4a and RASSF1A (RAS association domain family protein 1) are candidate tumor suppressor genes in cervical cancer. Inactivation of these genes may be due to aberrant DNA hypermethylation of $\mathrm{CpG}$ islands in the promoter region, and a relationship between development of cervical cancer and such epigenetic changes has been proposed (5-7). Inactivation of cell-cycle checkpoint genes in tumor cells by aberrant DNA hypermethylation also has a major effect on sensitivity to specific antitumor agents $(8,9)$. Mitotic checkpoint gene $C H F R$ (checkpoint with forkhead and ring finger) is located in chromosome 12q24.33 and has the function of delaying chromatin aggregation, leading to delayed progression to mitosis (10). The CHFR gene has a forkhead-associated domain in the $\mathrm{N}$-terminal region and a ring finger domain in the center region. Both domains function as a mitotic checkpoint by detecting mitotic stress, and under such conditions CHFR induces cell cycle arrest in G2 phase (G2 arrest) to allow repair of damaged DNA.

Taxane is a microtubule depolymerization inhibitor in mitotic cells. Cells with normal CHFR expression are arrested in G2 phase to repair damaged DNA and consequently are resistant to taxane. However, cells with a CHFR gene inactivated by aberrant hypermethylation cannot detect DNA damage and proceed to mitosis, with subsequent cell death due to mitotic catastrophe; i.e., such cells show high sensitivity to taxane. Therefore, aberrant hypermethylation of the CHFR gene is a potential molecular marker for taxane sensitivity. A relationship between aberrant hypermethylation of $C H F R$ and sensitivity to taxanes has been reported in 
colon, gastric and endometrial cancer cells in vitro $(9,11,12)$, but has not been studied in cervical cancer. Therefore, we investigated this relationship in cervical cancer cells, with the goal of establishing a new molecular marker for selection of therapy for cervical cancer.

\section{Materials and methods}

Subjects and cytologic specimens. Samples were obtained from 20 normal cervical smears and 40 cervical cancer smears. After obtaining informed consent, cervical smears were collected using the ThinPrep collecting system (Cytyc Corporation, Boxborough, MA) and kept in preservation fluid (PreservCyt Solution, Cytyc Corp.) (13). Pathological diagnosis was confirmed by cervical histology, and the cytological and histological results were consistent for all 60 smears. Of the 40 cervical cancer smears, 26 were squamous carcinoma and 14 were adenocarcinoma. The histological type and stage were determined according to the General Rules for Clinical Cervical Cancer in Japan published by the Japan Society of Obstetrics and Gynecology.

Cultured cell lines. The human cervical squamous cell carcinoma-derived cell lines, SKG-I, SKG-II, SKG-IIIa and SKG-IIIb, and the human cervical adenocarcinoma-derived cell lines, HeLa and TCO-I, were used in the study. HeLa cells were incubated in DMEM (Sigma, St. Louis, MO) with $10 \%$ fetal bovine serum (FBS) (Sanko Junyaku Co., Ltd., Tokyo, Japan) and TCO-I cells were incubated in MEM medium (Sigma) with 10\% FBS. All other cell lines were incubated in F12 medium (Sigma) with $10 \%$ FBS. Cells were incubated in $10-\mathrm{cm}$ dishes at $37^{\circ} \mathrm{C}$ in a $5 \% \mathrm{CO}_{2}$ atmosphere.

DNA extraction and methylation-specific PCR (MSP) assay of the CHFR gene. DNA was extracted from 60 cervical smears and 6 cervical carcinoma-derived cell lines using a Get Pure DNA Kit (Dojin Glocal Corporation, Kumamoto, Japan). DNA $(1 \mu \mathrm{g})$ extracted from cervical smears was diluted with $50 \mu 1$ of distilled water and incubated in $5.5 \mu 1$ of $3 \mathrm{~N} \mathrm{NaOH}$ at $37^{\circ} \mathrm{C}$ for $15 \mathrm{~min}$. To this solution, $30 \mu \mathrm{l}$ of $10 \mathrm{mM}$ hydroquinone (Sigma) and $520 \mu \mathrm{l}$ of $3 \mathrm{M}$ sodium bisulfite (prepared at pH 5.5 with $10 \mathrm{~N} \mathrm{NaOH}$, Sigma) were added with mixing. Mineral oil was laid over the solution to prevent evaporation, and the solution was incubated overnight at $50^{\circ} \mathrm{C}$. The lower layer of the reaction solution was mixed with $1 \mathrm{ml}$ of Clean-up Resin (Promega Corporation, Madison, WI) and then injected into a column. After rinsing with $2 \mathrm{ml}$ of $80 \%$ isopropanol, the mixture was centrifuged at $15,000 \mathrm{rpm}$ for $3 \mathrm{~min}$ to completely remove isopropanol. Hot $\left(70^{\circ} \mathrm{C}\right)$ distilled water $(50 \mu \mathrm{l})$ was added, and the mixture was centrifuged at 15,000 rpm for $2 \mathrm{~min}$ to elute DNA. The DNA was then incubated with $5.5 \mu 1$ of $2 \mathrm{~N} \mathrm{NaOH}$ at $37^{\circ} \mathrm{C}$ for $20 \mathrm{~min}$. Next, $66 \mu \mathrm{l}$ of $5 \mathrm{~N}$ ammonium acetate and $243 \mu 1$ of $95 \%$ ethanol were added and the mixture was incubated at $-80^{\circ} \mathrm{C}$ for $1 \mathrm{~h}$ and centrifuged at $15,000 \mathrm{rpm}$ for $30 \mathrm{~min}$ to precipitate DNA. Supernatant exceeding $50 \mu 1$ was removed, $1 \mathrm{ml}$ of $60 \%$ ethanol was added, and the mixture was centrifuged at 15,000 rpm for $30 \mathrm{~min}$ and rinsed. The precipitated DNA was dried in air and dissolved in $20 \mu 1$ of distilled water. DNA solution (2 $\mu \mathrm{l})$ was used as the MSP template. In the PCR assay, AmpliTaq Gold and 10x PCR buffer/ $\mathrm{MgCl}_{2}$ with dNTP (Applied Biosystems, Foster City, CA) were used and the results were analyzed with a GeneAmp PCR System 9700 (Applied Biosystems). The PCR conditions and primer sequence have been described previously (12). DNA extracted from the cultured cell lines was prepared similarly for use in MSP analysis of the CHFR gene.

RNA extraction and RT-PCR assay of CHFR expression. Total RNA from 6 cervical cancer-derived cell lines was extracted using an RNeasy mini-Kit (Qiagen, Valencia, CA). cDNA was synthesized from $1 \mu \mathrm{g}$ of total RNA using SuperScriptII Reverse Transcriptase (Invitrogen, Carlsbad, CA). CHFR expression was analyzed in an RT-PCR assay using $1 \mu \mathrm{l}$ of first-strand cDNA as template. AmpliTaq Gold and 10x PCR buffer/ $\mathrm{MgCl}_{2}$ with dNTP were used in the PCR assay, with analysis using a GeneAmp PCR System 9700 (Applied Biosystems). The PCR conditions and primer sequence have been described previously (12).

Demethylation treatment. Cervical carcinoma-derived HeLa cells with aberrant methylation of $C H F R$ were plated on a $10-\mathrm{cm}$ dish at $10^{6}$ cell/dish and incubated for $72 \mathrm{~h}$. 5-aza-dC (Sigma), a demethylating agent, was then added at a final concentration of $1 \mu \mathrm{M}$ in culture medium. After $48 \mathrm{~h}$ of incubation, 5-aza-dC was added again and DNA and RNA were extracted 24 and $72 \mathrm{~h}$ after the second addition of 5-aza-dC.

Cell-cycle analysis using flow cytometry. Cervical-carcinoma derived SNG-IIIa and HeLa cells were plated on a $10-\mathrm{cm}$ dish at $5 \times 10^{5}$ cell/dish and incubated until the cells reached $80 \%$ confluence. Paclitaxel (supplied by the Bristol-Myers Squibb Company) was added to the culture medium at a final concentration of $1.0 \mu \mathrm{g} / \mathrm{ml}$. The cells were trypsinized $48 \mathrm{~h}$ later and rinsed twice with PBS. Supernatant was separated from the cell pellets by centrifugation at 15,000 rpm for $5 \mathrm{~min}$, and $500 \mu 1$ of PBS was added to the pellets and the mixture was pipetted well. As the mixture was vortexed, $1 \mathrm{ml}$ of cool $100 \%$ ethanol was added. The mixture was then incubated at room temperature for $30 \mathrm{~min}$ for cell fixation. The cells were rinsed twice with PBS and $500 \mu \mathrm{l}$ of RNase was added to the pellets after supernatant removal. The cells were then incubated at room temperature for $20 \mathrm{~min}$. Subsequently, $500 \mu 1$ of propidium iodide (PI) solution was added, the mixture was poured into a cell strainer, and the cell cycle was determined by flow cytometry using an EpicsXL MCL (Beckman Coulter, Inc, Fullerton, CA).

In vitro test of sensitivity to anticancer agents. The sensitivity to anti-cancer agents of 6 cervical carcinomaderived cell lines was determined using the collagen gel droplet embedded culture drug sensitivity test (CD-DST) (14). Cervical carcinoma-derived cells were pretreated with cell dispersion enzyme EZ (Nitta Gelatin Inc., Tokyo, Japan) for $2 \mathrm{~h}$, followed by centrifugation to collect the cells. In a flask containing collagen gel, the cells were pre-incubated for $24 \mathrm{~h}$ and surviving cells that adhered to collagen gel were collected. Cellmatrix Type CD solution was added to the 


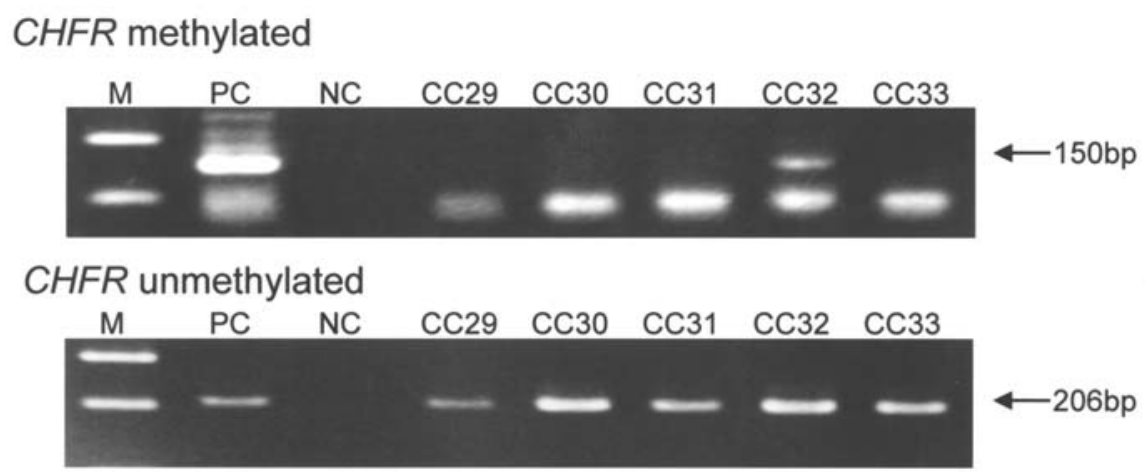

M: marker; PC: positive control; NC: negative control; CC: cervical cancer.

Figure 1. MSP analysis of the CHFR gene in cervical cancer cytologic specimens. MSP analysis was examined with DNA extracted from cervical cancer cytologic specimens. A band due to aberrant methylation is observed at CC32.

collected cells, and the suspension of cells and collagen gel was dropped onto a 6-well plate to prepare 3 drops of $30 \mu 1$ each. The suspension was left to stand in an incubator at $37^{\circ} \mathrm{C}$ in a $5 \% \mathrm{CO}_{2}$ atmosphere for $1 \mathrm{~h}$ for gelling and then overlaid with $4 \mathrm{ml} /$ well of medium. An anticancer agent was then added to the suspension: cisplatin, doxorubicin, paclitaxel, docetaxel, 5-fluorouracil and etoposide at final concentrations of $2.0,0.02,1.0,0.1,1.0$ and $1.0 \mu \mathrm{g} / \mathrm{ml}$, respectively. After $24 \mathrm{~h}$, the drugs were removed by rinsing and the cells were incubated without serum at $37^{\circ} \mathrm{C}$ in $5 \%$ $\mathrm{CO}_{2}$ for 7 days. The cells were dyed with Neutral Red, fixed with formalin and dried. Images were collected by scanning using an image analyzer and the ratio of surviving cells in the anticancer agent-treated group (T) to that in the nontreated group (C) (T/C ratio) was determined. In general, cells are considered to be highly sensitive to the agent when the $\mathrm{T} / \mathrm{C}$ ratio is $\leq 40 \%$.

Transfection of small interfering RNA (siRNA). SKG-IIIa cells were plated on a $60-\mathrm{mm}$ dish at $4 \times 10^{5}$ cell/dish and transfected $48 \mathrm{~h}$ later with siRNA using siFECTOR (B-Bridge International Inc, CA). In this procedure, $4.5 \mu \mathrm{l}$ of siRNA stock solution $(100 \mu \mathrm{M})$ and $295.5 \mu 1$ of serum-free MEM were mixed in a test tube. In another tube, $13.5 \mu 1$ of siFECTOR and $286.5 \mu 1$ of serum-free MEM were mixed. The solutions from the two tubes were mixed and incubated at room temperature for $30 \mathrm{~min}$. Each dish containing SKGIIIa cells was rinsed twice with $2 \mathrm{ml}$ of serum-free MEM and $2.4 \mathrm{ml}$ of serum-free MEM was then added. The incubated siRNA mixture solution was added to the dish at $0.6 \mathrm{ml} / \mathrm{dish}$ and incubated at $37^{\circ} \mathrm{C}$ in $5 \% \mathrm{CO}_{2}$ for $6 \mathrm{~h}$. After incubation, $3 \mathrm{ml}$ of MEM containing $20 \%$ serum was added to the dish. S20C-0600 (B-Bridge International) was used as negative control siRNA. The siRNA sequence corresponding to the CHFR gene was 5'-GGAAAAACAUGUUGACCGAdTdT-3'. The expression levels of mRNA and protein were determined $48 \mathrm{~h}$ after siRNA addition. Anticancer agents were added $48 \mathrm{~h}$ after siRNA addition and the sensitivity of the cells to each agent was analyzed using the CD-DST.

Immunoblotting. SKG-IIIa cells were rinsed with PBS, trypsinized and centrifuged at $15,000 \mathrm{rpm}$ for $5 \mathrm{~min}$ at $4^{\circ} \mathrm{C}$.
Protein was extracted using a Mammalian Cell Extraction Kit (Bio Vision Research Products, CA) according to the manufacturer's protocol. The sample (200 $\mu \mathrm{g}$ of protein) was mixed with sample buffer (Bio-Rad Laboratories, CA) containing the equivalent volume of $5 \%$ B-mercaptoethanol (Bio-Rad Laboratories) and the mixture was boiled for $5 \mathrm{~min}$. After boiling, the mixture was electrophoresed on a $10 \%$ polyacrylamide gel and the proteins were transferred to nitrocellulose membranes (Bio-Rad Laboratories). The membranes were soaked in PBS containing $1 \%$ BSA and $0.1 \%$ Tween-20 and incubated at room temperature for $1 \mathrm{~h}$ for blocking. They were then reacted with anti- $\beta$-actin antibody (A5316 Sigma-Aldrich Inc, St. Louis, MO, 5,000-fold diluted) and anti-CHFR antibody (ab13773, Abcam, Cambridge, UK, 500 -fold diluted) at $4^{\circ} \mathrm{C}$ overnight, followed by rinsing three times with PBS containing $0.1 \%$ Tween (PBS-T) for $10 \mathrm{~min}$ each. The anti- $\beta$-actin and anti-CHFR antibodies were reacted with anti-mouse IgG antibody (PK-6102, Vector Laboratories, Inc., CA) and anti-goat IgG antibody (BA5000, Vector Laboratories, 250-fold diluted), respectively, at room temperature for $1 \mathrm{~h}$. The membranes were rinsed with PBS-T three times and reacted with $\mathrm{ABC}$ complex (PK6102 , Vector Laboratories, pre-reacted at $4^{\circ} \mathrm{C}$ for $30 \mathrm{~min}$ ) at room temperature for $1 \mathrm{~h}$. The membranes were rinsed with PBS-T twice and PBS once, and visualized with DAB (Sigma).

\section{Results}

Results from MSP analysis of cervical cancer cytologic specimens are shown in Fig. 1. Aberrant hypermethylation of the CHFR gene in the promoter region was detected in $14.3 \%(2 / 14)$ of adenocarcinoma specimens, whereas there was no aberrant DNA hypermethylation in normal cervical cells and squamous cell carcinoma cells (Fig. 1, Tables I and II). Aberrant hypermethylation of $C H F R$ was also analyzed in 6 human cervical carcinoma-derived cell lines and was detected in SKG-IIIb and HeLa cells. RT-PCR analysis confirmed that expression of mRNA for $C H F R$ was reduced in SKG-IIIb and HeLa cells (Fig. 2). The sensitivity of the cell lines to paclitaxel and docetaxel was determined using the CD-DST, and SKG-IIIb and HeLa cells showed much 
Table I. Aberrant methylation of the CHFR gene in cervical cancer cytologic specimens.

\begin{tabular}{|c|c|c|c|}
\hline No. & Tissue type & Stage & CHFR \\
\hline CC1 & SCC & Ib1 & $\mathrm{U}$ \\
\hline $\mathrm{CC} 2$ & SCC & Ib1 & $\mathrm{U}$ \\
\hline CC3 & $\mathrm{SCC}$ & Ib1 & $\mathrm{U}$ \\
\hline $\mathrm{CC} 4$ & $\mathrm{SCC}$ & Ib1 & $\mathrm{U}$ \\
\hline CC5 & SCC & IIa & $\mathrm{U}$ \\
\hline CC6 & SCC & IIa & $\mathrm{U}$ \\
\hline CC7 & SCC & $\mathrm{Ib} 2$ & $\mathrm{U}$ \\
\hline CC8 & SCC & $\mathrm{IIb}$ & $\mathrm{U}$ \\
\hline CC9 & $\mathrm{SCC}$ & Ib1 & $\mathrm{U}$ \\
\hline CC10 & SCC & Ib1 & $\mathrm{U}$ \\
\hline CC11 & $\mathrm{SCC}$ & Ib1 & $\mathrm{U}$ \\
\hline CC12 & SCC & $\mathrm{Ib} 2$ & $\mathrm{U}$ \\
\hline CC13 & SCC & Ib1 & $\mathrm{U}$ \\
\hline $\mathrm{CC} 14$ & $\mathrm{SCC}$ & Ib1 & $\mathrm{U}$ \\
\hline CC15 & SCC & Ib1 & $\mathrm{U}$ \\
\hline CC16 & SCC & IIa & $\mathrm{U}$ \\
\hline CC17 & SCC & $\mathrm{Ib} 2$ & $\mathrm{U}$ \\
\hline CC18 & SCC & $\mathrm{Ib} 2$ & $\mathrm{U}$ \\
\hline CC19 & $\mathrm{SCC}$ & Ib1 & $\mathrm{U}$ \\
\hline CC20 & $\mathrm{SCC}$ & $\mathrm{Ib} 2$ & $\mathrm{U}$ \\
\hline $\mathrm{CC} 21$ & SCC & Ib1 & $\mathrm{U}$ \\
\hline $\mathrm{CC} 22$ & $\mathrm{SCC}$ & Ib1 & $\mathrm{U}$ \\
\hline CC23 & SCC & $\mathrm{Ib} 2$ & $\mathrm{U}$ \\
\hline CC24 & SCC & Ib1 & $\mathrm{U}$ \\
\hline CC25 & SCC & Ib1 & $\mathrm{U}$ \\
\hline CC26 & SCC & IIb & $\mathrm{U}$ \\
\hline $\mathrm{CC} 27$ & MAD & Ib1 & $\mathrm{U}$ \\
\hline CC28 & MAD & IIa & M \\
\hline CC29 & MAD & Ib1 & $\mathrm{U}$ \\
\hline CC30 & MAD & Ib1 & $\mathrm{U}$ \\
\hline CC31 & MAD & Ib1 & $\mathrm{U}$ \\
\hline CC 32 & MAD & Ib1 & M \\
\hline CC33 & MAD & IIa & $\mathrm{U}$ \\
\hline CC34 & MAD & Ib1 & $\mathrm{U}$ \\
\hline CC35 & MAD & Ib1 & $\mathrm{U}$ \\
\hline CC36 & MAD & Ib1 & $\mathrm{U}$ \\
\hline CC37 & MAD & $\mathrm{Ib} 2$ & $\mathrm{U}$ \\
\hline CC38 & MAD & Ib1 & $\mathrm{U}$ \\
\hline CC39 & MAD & Ib1 & $\mathrm{U}$ \\
\hline $\mathrm{CC} 40$ & MAD & $\mathrm{IIb}$ & $\mathrm{U}$ \\
\hline
\end{tabular}

CC, cervical cancer; SCC, squamous cell carcinoma; MAD, mucinous adenocarcinoma (endocervical type).

higher high sensitivity to these agents, compared to other cells (Table III).

Recovery of CHFR expression by treatment with 5-aza$\mathrm{dC}$ was examined in HeLa cells (which showed aberrant CHFR hypermethylation), and increased CHFR expression
Table II. Aberrant methylation frequency of the CHFR gene in cervical cancer cytologic specimens.

\begin{tabular}{llr}
\hline & \multicolumn{2}{c}{ CHFR } \\
\cline { 2 - 3 } & $\mathrm{M}(\%)$ & $\mathrm{U}(\%)$ \\
\hline $\mathrm{NCE}$ & $0(0)$ & $20(100)$ \\
$\mathrm{SCC}$ & $0(0)$ & $26(100)$ \\
MAD & $2(14.3)$ & $12(85.7)$ \\
\hline NCE, normal cervical epithelium; SCC, squamous cell carcinoma; & \\
MAD, mucinous adenocarcinoma (endocervical type); M, methylated; \\
\hline
\end{tabular}

following 5-aza-dC treatment was confirmed by RT-PCR (Fig. 3). Changes in the sensitivity of HeLa cells and SKGIIIa cells (which did not show aberrant CHFR hypermethylation) to 6 anticancer agents were determined before and after 5-aza-dC addition, using the CD-DST. Anticancer agents other than taxanes (5-fluorouracil, etoposide, cisplatin and doxorubicin) showed almost no change in the $\mathrm{T} / \mathrm{C}$ ratio before and after 5-aza-dC addition and regardless of aberrant CHFR hypermethylation. In contrast, the T/C ratios of HeLa cells treated with paclitaxel and docetaxel increased significantly after 5-aza-dC addition, indicating a significant decrease in sensitivity (Table IV).

Changes in cell cycle were determined using flow cytometry in SKG-IIIa and HeLa cells treated with paclitaxel alone or a combination of paclitaxel and 5-aza-dC. In SKG-IIIa cells (no aberrant CHFR methylation), cells in $\mathrm{G} 2 / \mathrm{M}$ phase markedly increased to $73.9 \%$ after paclitaxel treatment and G2 arrest was observed. In contrast, in HeLa cells (aberrant CHFR hypermethylation), the percentage of G2/M cells remained low (8.3\%) after paclitaxel treatment and Sub-G1 cells increased to $13.4 \%$, higher than that of controls, suggesting that paclitaxel treatment induced apoptosis. However, combined treatment with paclitaxel and 5 -aza-dC resulted in $73.9 \%$ of cells in the G2/M phase and a marked decrease in Sub-G1 cells to $2.2 \%$, showing a similar pattern to paclitaxel treatment of SKG-IIIa cells (Fig. 4).

SKG-IIIa cells were transfected with siRNA for $C H F R$ and the expression levels of CHFR mRNA and protein decreased to approximately half of the control levels (Fig. 5). Under these conditions, changes in sensitivity to anticancer agents were determined using the CD-DST. The T/C ratios for paclitaxel and docetaxel were significantly decreased compared with those for non-taxane anticancer agents, indicating that reduction of CHFR expression specifically increases sensitivity to taxanes (Fig. 6).

\section{Discussion}

Aberrant hypermethylation of the CHFR gene has been reported in endometrial, gastrointestinal and lung cancers $(12,15-17)$. A similar effect has not been studied in cervical cancer, and the relationship between aberrant CHFR hypermethylation and the biological characteristics of cervical 


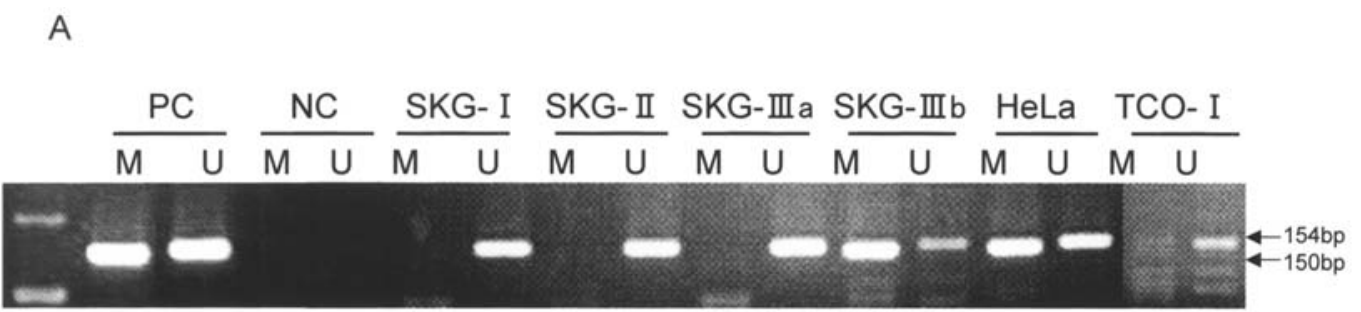

PC: positive control; NC: negative control; M: methylated; U: unmethylated.

B

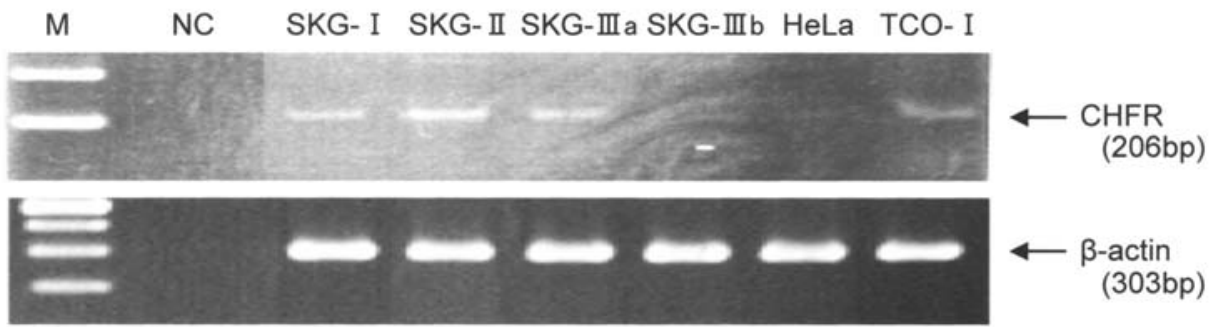

M: marker; NC: negative control.

Figure 2. (A) MSP analysis of the CHFR gene in cervical cancer-derived cell lines. Aberrant hypermethylation of the $C H F R$ gene was observed in SKG-IIIb and HeLa cells. (B) Analysis of CHFR expression in cervical cancer-derived cell lines using RT-PCR. CHFR expression was decreased in SKG-IIIb and HeLa cells, which had aberrant hypermethylation of the CHFR gene.

Table III. Sensitivity (T/C ratio) of cervical cancer-derived cells to various anticancer agents, assessed using the CD-DST.

\begin{tabular}{lccccc}
\hline Cell line & CHFR & Cisplatin (\%) & Doxorubicin (\%) & Paclitaxel (\%) & Docetaxel (\%) \\
\hline SKG-I & $\mathrm{U}$ & 75.9 & 89.6 & 39.5 & 41.3 \\
SKG-II & $\mathrm{U}$ & 97.8 & 91.6 & 55.5 & 49.6 \\
SKG-IIIa & $\mathrm{U}$ & 94.5 & 90.1 & 69.2 & 63.1 \\
SKG-IIIb & $\mathrm{M} / \mathrm{U}$ & 93.2 & 77.2 & 14.0 & 14.0 \\
HeLa & $\mathrm{M} / \mathrm{U}$ & 75.2 & 79.1 & 9.8 & 9.7 \\
TCO-I & $\mathrm{U}$ & 96.9 & 66.7 & 33.2 & 35.1 \\
\hline
\end{tabular}

M, methylated; U, unmethylated.

A
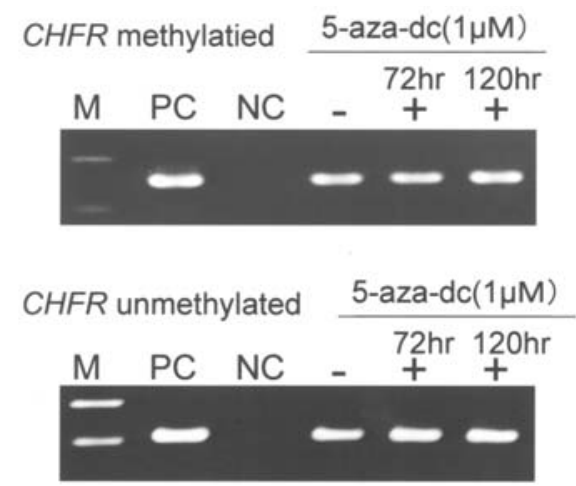
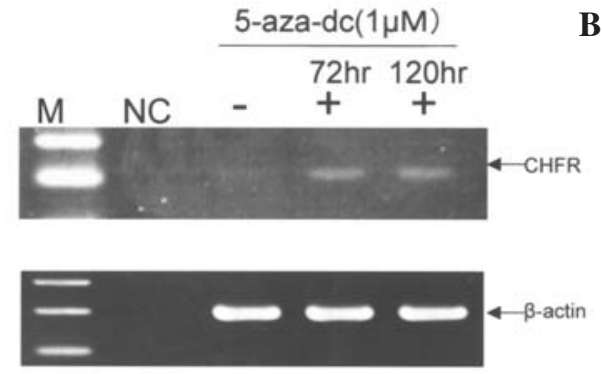

Figure 3. Demethylation analysis of the CHFR gene in HeLa cells. (A) MSP analysis after 5-aza-dC treatment. (B) CHFR expression recovered $72 \mathrm{~h}$ after 5 -aza-dC retreatment (RT-PCR).

cancer, including sensitivity to taxanes, is unclear. In this study, aberrant hypermethylation of CHFR was observed in adenocarcinoma cells at a rate of $14.3 \%$, but not in normal cervical cells and squamous cell carcinoma cells. Epigenetic 
Table IV. Changes in sensitivity (T/C ratio) of cervical cancer-derived cells to various anticancer agents by treatment with a demethylation agent.

\begin{tabular}{|c|c|c|c|c|c|c|c|c|c|c|c|c|c|}
\hline \multirow{2}{*}{$\begin{array}{l}\text { Cell } \\
\text { line }\end{array}$} & \multirow[b]{2}{*}{ CHFR } & \multicolumn{2}{|c|}{ 5-FU (\%) } & \multicolumn{2}{|c|}{ Etoposide (\%) } & \multicolumn{2}{|c|}{ Cisplatin (\%) } & \multicolumn{2}{|c|}{ Doxorubicin $(\%)$} & \multicolumn{2}{|c|}{ Paclitaxel (\%) } & \multicolumn{2}{|c|}{ Docetaxel (\%) } \\
\hline & & 5 aza (-) & $5 a z a(+)$ & $5 a z a($ & $5 a z a(+)$ & $5 a z a(-$ & 5 aza $(+)$ & 5 aza $(-)$ & $5 \mathrm{aza}(+)$ & $5 a z a(-)$ & 5 aza $(+)$ & $5 a z a(-$ & 5 aza $(+)$ \\
\hline SKG IIIa & $\mathrm{U}$ & 88.5 & 83.2 & 76.0 & 84.2 & 94.5 & 80.7 & 90.1 & 98.6 & 69.2 & 87.0 & 63.1 & 88.5 \\
\hline HeLa & $\mathrm{M} / \mathrm{U}$ & 71.4 & 84.6 & 46.3 & 55.9 & 75.2 & 70.9 & 79.1 & 81.2 & 9.8 & 51.4 & 9.7 & 57.1 \\
\hline
\end{tabular}

5aza, 5-aza-dc; M, methylated; U, unmethylated.

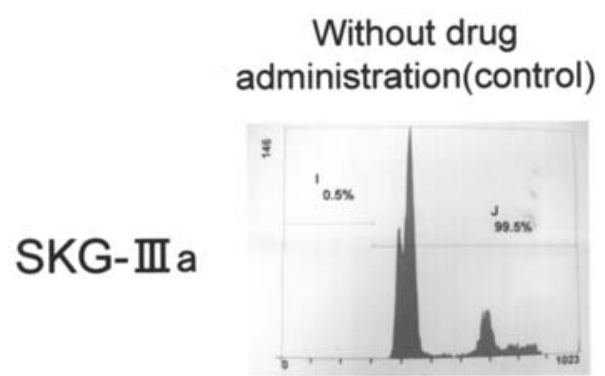

Sub G1: $0.5 \%$

G1: $75.9 \%$

S: $19.7 \%$

G2/M: $3.9 \%$

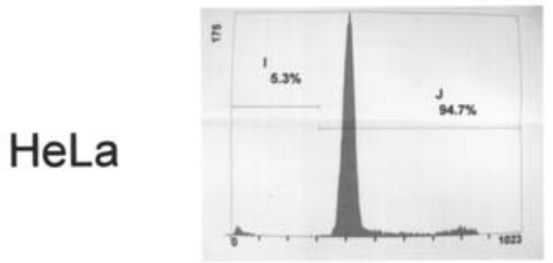

Sub G1: $\quad 5.3 \%$

G1: $81.1 \%$

S: $11.0 \%$

$\mathrm{G} 2 / \mathrm{M}: \quad 2.6 \%$

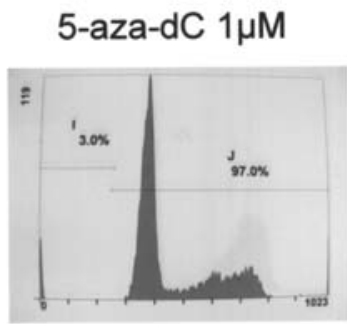

Sub G1: $3.0 \%$

G1: $61.6 \%$

S: $27.9 \%$

G2/M: $7.5 \%$

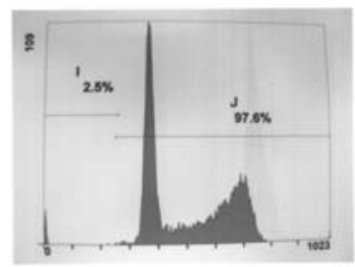

Sub G1: $2.5 \%$

G1: $42.7 \%$

S: $39.2 \%$

G2/M: $15.6 \%$

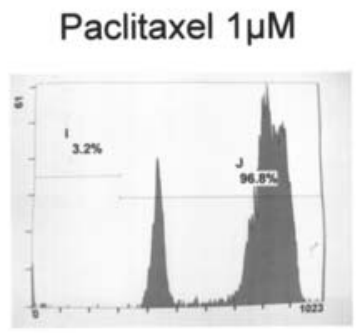

Sub G1: $3.2 \%$

G1: $16.7 \%$

S: $6.2 \%$

G2/M: $73.9 \%$

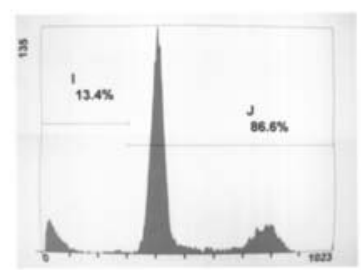

Sub G1: $13.4 \%$

G1: $65.0 \%$

S: $13.3 \%$

G2/M: $8.3 \%$
Paclitaxel $1 \mu \mathrm{M}$ +5-aza-dC $1 \mu \mathrm{M}$

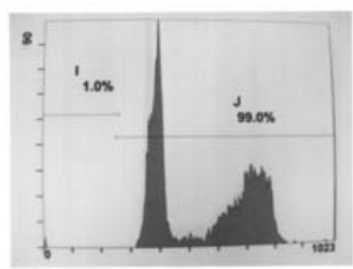

Sub G1: $1.0 \%$

G1: $42.5 \%$

S: $27.9 \%$

G2/M: $28.6 \%$

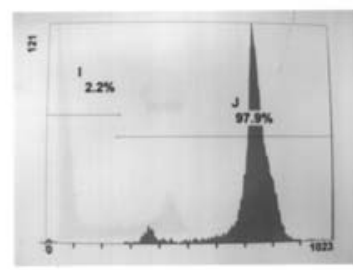

Sub G1: $2.2 \%$

G1: $4.2 \%$

S: $19.7 \%$

G2/M: $73.9 \%$

Figure 4. Cell-cycle analysis of SKG-IIIa and HeLa cells using flow cytometry. In SKG-IIIa cells after treatment with paclitaxel alone, the percentage of cells in the G2/M phase was high and that of cells in the Sub-G1 phase did not change markedly. In HeLa cells with paclitaxel alone, the percentage of cells in the G2/M phase was low and that of cells in the Sub-G1 phase increased. In contrast, after treatment with a combination of paclitaxel and 5-aza-dC, cells in the G2/M phase markedly increased and those in the Sub-G1 phase decreased to a level similar to that of the control.

inactivation of CHFR has also been observed in endometrial cancer cells, suggesting that aberrant hypermethylation may play an important role in development of uterine cancer, and specifically in adenocarcinoma. There has been a recent increase in cases of cervical cancer, especially in women aged up to 35 years (18-20), and cervical adenocarcinoma has markedly different biological characteristics from squamous cell carcinoma; these characteristics include high nodal metastasis, a refractory nature, poor outcome, and severe malignancy (21-23). The CHFR gene negatively regulates the Aurora-A gene, a mitotic kinase; hence, suppression of CHFR expression increases Aurora-A expression (24).
Aurora-A overexpression is reported to induce chromosomal instability (CI) and lead to a poor prognosis in ovarian, breast and bladder cancers (25-27), and a similar mechanism might underlie the characteristics of cervical adenocarcinoma.

Cell-cycle analysis of cervical cancer-derived cells using flow cytometry showed an increase in G2/M cells after paclitaxel treatment in cells with a normal CHFR gene. In cells with $C H F R$ inactivated epigenetically by aberrant hypermethylation, paclitaxel treatment alone resulted in only a small number of $\mathrm{G} 2 / \mathrm{M}$ cells, whereas treatment with a combination of paclitaxel and a demethylation agent caused a marked increase in $\mathrm{G} 2 / \mathrm{M}$ cells. These results strongly 
A

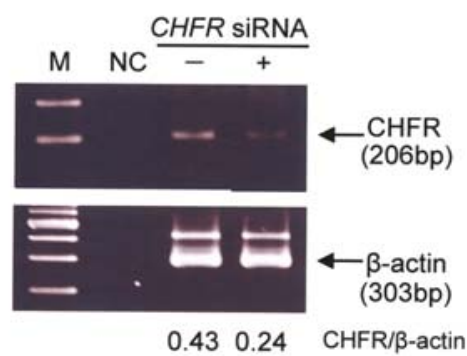

B

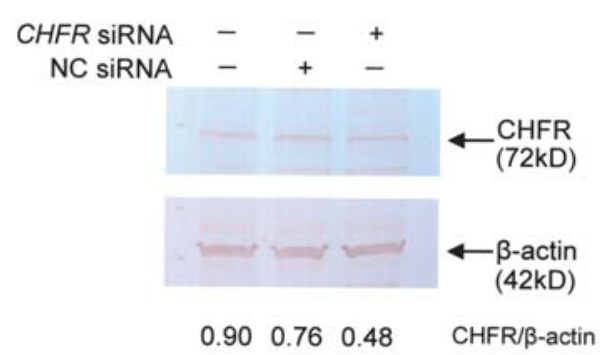

M: marker; NC: negative control; siRNA: small interfering RNA.

Figure 5. siRNA-induced suppression of CHFR expression in SKG-IIIa cells. (A) RT-PCR, (B) Western blotting. siRNA suppressed expression of mRNA and protein to approximately $50 \%$ of control levels.

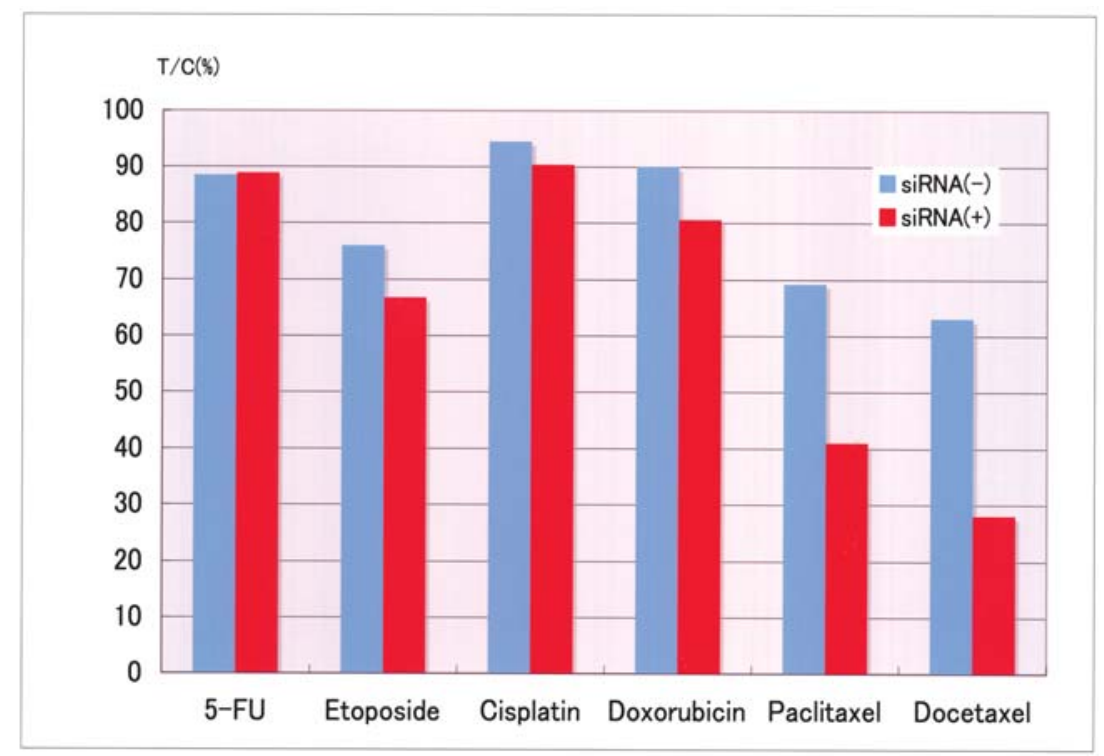

siRNA: small interfering RNA of CHFR.

Figure 6. siRNA-induced changes in sensitivity (T/C ratio) of SKG-IIIa cells to various anticancer agents. After suppression of CHFR expression, the sensitivity to taxanes alone was increased.

support the hypothesis that when tumor cells are treated with taxane, cells with normal $C H F R$ expression undergo arrest in G2 phase to repair damaged DNA and are resistant to taxane, whereas cells with an inactivated CHFR gene due to aberrant hypermethylation cannot detect DNA damage and proceed to mitosis, thereby showing high sensitivity to taxane. This mechanism was apparent in cells with inactivated $C H F R$ genes following paclitaxel treatment, which caused an increase in Sub-G1 cells, rather than G2/M cells, indicating progression to mitosis and subsequent cell death due to the mitotic catastrophe.

In CD-DST analysis of the sensitivity of HeLa cells to anticancer agents, demethylation significantly reduced the sensitivity to taxanes. Treatment with 5 -aza-dC is likely to demethylate various genes, in addition to $C H F R$. However, we also confirmed that suppression of CHFR in siRNA-transfected SKG-IIIa cells did not alter sensitivity to cisplatin and doxorubicin, but specifically to taxanes (paclitaxel and docetaxel). This result suggests that epigenetic inactivation of the $C H F R$ gene specifically contributed to taxane sensitivity. Therefore, aberrant hypermethylation of $C H F R$ may be a molecular marker for prediction of the sensitivity of cervical cancer (and especially cervical adenocarcinoma) to taxane therapy. As discussed above, cervical adenocarcinoma is more refractory and shows a poorer response to anticancer agents compared with squamous carcinoma. Clinical responses of cervical adenocarcinoma are $20 \%$ with cisplatin, $14 \%$ with 5-fluorouracil, and $12 \%$ with etoposide, which are slightly lower than those for squamous carcinoma (28). However, in cervical adenocarcinoma with higher epigenetic inactivation of CHFR gene compared to squamous carcinoma, the clinical response to paclitaxel alone is $31 \%$, $17 \%$ higher than with any other agent (29), and these findings are consistent with our results. 
The CD-DST can be used to test chemosensitivity to anticancer agents using a small number of cells in a threedimensional culture, and can be analyzed by cultured cells and specimens in the same system. This method has also been reported to show a strong correlation with clinical response in gynecological tumors (14). Therefore, the aberrant hypermethylation of the CHFR gene may be useful for a molecular marker for selection of therapy for cervical cancer. Furthermore, transfection of siRNA for CHFR increased the sensitivity of cervical squamous carcinoma to taxanes without affecting the sensitivity to other anticancer agents. This approach may be applicable to preoperative chemotherapy for stage Ib and IIb patients, and may offer a new therapeutic strategy for cervical cancer.

\section{Acknowledgments}

This study was partially supported by a 2006 Keio University Grant-in-Aid for Encouragement of Young Medical Scientists, a 2006 research grant by the Keio Health Counseling Center, a 2007 grant from the Sato Memorial Foundation for Cancer Research, a 2007 Grant-in-Aid for Scientific Research from the Japan Society for the Promotion of Science, and a Grantin-Aid for Young Scientists (B) (study No. 19791163). We would like to express our gratitude to the Cytyc Corporation for their support of ThinPrep.

\section{References}

1. Beral V, Hermon C, Muñoz N and Devesa SS: Cervical cancer. Cancer Surv 19-25: 265-285, 1994.

2. Parker SL, Tong T, Bolden S and Wingo PA: Cancer statistics, 1997. CA Cancer J Clin 47: 5-27, 1997.

3. Scheffiner M, Werness BA, Huibregtse JM, Levine AJ and Howly PM: The E6 oncoprotein ebcode by human papillomavirus types 16 and 18 promotes the degradation of $\mathrm{p} 53$. Cell 63: 1129-1135, 1990.

4. Dyson N, Howley PM, Münger K and Harlow E: The human papillomavirus $16 \mathrm{E} 7$ oncoprotein is able to bund to the retinoblastoma gene product. Science 243: 934-937, 1989.

5. Nakashima R, Fujita M, Enomoto T, Haba T, Yoshino K, Wada H, Kurachi H, Sasaki M, Wakasa K, Inoue M, Buzard G and Murata Y: Alteration of p16and p15 gene in human uterine tumors. Br J Cancer 80: 458-467, 1999.

6. Yu MY, Tong JH, Chan PK, Lee TL, Chan MW, Chan AW, Lo KW and To KF: Hypermethylation of the tumor suppressor gene RASSF1A and frequent concomitant loss of heterozygosity at 3p21 in cervical cancers. Int J Cancer 105: 204-209, 2003.

7. Kuzmin I, Liu L, Dammann R, Geil L, Stanbridge EJ Wilczynski SP, Lerman MI and Pfeifer GP: Inactivation of RAS assoiciation domain family $1 \mathrm{~A}$ gene in cervical carcinomas and the role of human papillomavirus infection. Cancer Res 63: 1888-1893, 2003.

8. Suzuki H, Itoh F, Toyota M, Kikuchi T, Kakiuchi H and Imai K: Inactivation of the 4-3-3 sigma gene is associated with 5' $\mathrm{CpG}$ island hypermethylation in human cancers. Cancer Res 60: 4353-4357, 2000

9. Satoh A, Toyota M, Itoh F, Sasaki Y, Suzuki H, Ogi K, Kikuchi T, Mita H, Yamashita T, Kojima T, Kusano M, Fujita M, Hosokawa M, Endo T, Tokino T and Imai K: Epigenetic inactivation of CHFR and sensitivity to microtubule inhibitors in gastric cancer. Cancer Res 63: 8606-8613, 2003.

10. Scolnick DM and Halazonetis TD: Chfr defines a mitotic stress checkpoint that delays entry into metaphase. Nature 406: 430-435, 2000

11. Toyota M, Sasaki Y, Satoh A, Ogi K, Kikuchi T, Suzuki H, Mita H, Tanaka N, Itoh F, Issa JP, Jair KW, Schuebel KE, Imai T and Tokino T: Epigenetic inactivation of CHFR in human tumors. Proc Natl Acad Sci USA 100: 7818-7823, 2003.
12. Yanokura M, Banno K, Kawaguchi M, Hirao N, Hirasawa A, Susumu N, Tsukazaki K and Aoki D: Relationship of abbarant DNA hypermethylation of CHFR with sensitivity to taxanes in endometrial cancer. Oncol Rep 17: 41-48, 2007.

13. Susumu N, Aoki D, Noda T, Nagashima Y, Hirao T, Tamada Y, Banno K, Suzuki A, Suzuki N, Tsuda H, Inazawa J and Nozawa S: Diagnostic clinical application of two-color fluorescence in situ hybridization that detects chromosome 1 and 17 alterations to direct touch smear and liquid-based thinlayer cytologic preparations of endometrial cancers. Int J Gynecol Cancer 15: 70-80, 2005.

14. Kawaguchi M, Banno K, Susumu N, Yanokura M, Kuwabara Y, Hirao N, Tsukazaki K and Nozawa S: Successful analysis of anticancer drug sensitivity by CD-DST using pleural fluid and ascites from patients with advanced ovarian cancer: case reports. Anticancer Res 25: 3547-3551, 2005.

15. Tokunaga E, Oki E, Nishida K, Koga T, Yoshida R, Ikeda K, Kojima A, Egashira A, Morita N, Kakeji Y and Maehara Y: Aberrant hypermethylation of the promoter region of the CHFR gene is rare in primary breast cancer. Breast Cancer Res Treat 97: 199-203, 2006.

16. Corn PG, Summers MK, Fogt F, Virmani AK, Halazonetis TD and EL-Deiry WS: Frequent hypermethylation of the 5' CpG island of the mitotic stress checkpoint gene Chfr in colorectal and non-small cell lung cancer. Carcinogenesis 24: 47-51, 2003

17. Mizuno K, Osada H, Konishi H, Tatematsu Y, Yatabe Y, Mitsudomi T, Fujii Y and Takahashi T: Aberrant hypermethylation of the CHFR prophase checkpoint gene in human lung cancers. Oncogene 21:2328-2333, 2002.

18. Sasieni $\mathrm{P}$ and Adams J: Changing rates of adenocarcinoma and adenosquamous carcinoma of the cervix in England. Lancet 357: 1490-1493, 2001.

19. Bray F, Carstensen B, Moller H, Zappa M, Zakelj MP, Lawrence G, Hakama M and Weidrepass E: Incidence trends of adenocarcinoma of the cervix in 13 European countries. Cancer Epidemiol Biomarkers Prev 14: 2191-2199, 2005.

20. Wang SS, Sherman ME, Hildesheim A, Lacey JV and Devesa S: Cervical adenocarcinoma and squamous cell carcinoma incidence trends among white women and black women in United States for 1976-2000. Cancer 100: 1035-1044, 2004

21. Berek JS, Hacker NF, Fu YS, Sokale JR, Leuchter RC and Lagasse LD: Adenocarcinoma of the uterine cervix: histologic variables associated with lymph node metastasis and survival. Obstet Gynecol 65: 46-52, 1985.

22. Irie T, Kigawa J, Minagawa Y, Itamochi H, Sato S, Akeshima R and Terakawa N: Prognosis and clinopathological characteristics of Ib-IIb adenocarcinoma of the uterine cervix in patients who have radical hysterectomy. Eur J Surg Oncol 26: 464-467, 2000.

23. Bulk S, Visser O, Rozendaal L, Verheijen RH and Meijer CJ: Incidence and survival rate of women with cervical cancer in the Greater Amsterdam area. Br J Cancer 89: 834-839, 2003.

24. Yu X, Minter-Dykhouse K, Malureanu L, Zhao WM, Zang D, Merkle CJ, Ward JM, Saya H, Fang G, van Deursen J and Chen J: Chfr is required for tumor suppression and Aurora A regulation. Nat Genet 37: 401-406, 2005.

25. Hu W, Kavanagh JJ, Deaver M, Johnston DJ, Freedman RS, Verschraegen CF and Sen S: Frequent overexpression of STK15/ Aurora-A/BTAK and chromosomal instability in tumorigenic cell cultures derived from human ovarian cancer. Oncol Res 15: 49-57, 2005.

26. Li JJ, Weroha SJ, Lingle WL, Papa D, Salisbury JL and Li SA Estrogen mediates Aurora-A overexpression, centrosome amplification, chromosomal instability, and breast cancer in female ACI rats. Proc Natl Acad Sci USA 101: 18123-18128, 2004.

27. Fraizer GC, Diaz MF, Lee IL, Grossman HB and Sen S: Aurora-A/STK15/BTAK enhances chromosomal instability in bladder cancer cells. Int J Oncol 25: 1631-1639, 2004

28. Thigpen JT, Blessing JA, Fowler WC Jr and Hatch K: Phase II trials of cisplatin and piperazinedione as single agent in the treatment of advanced or recuirrent non-squamous cell carcinoma of the cervix: a Gynecologic Oncology Group Study. Cancer Treat Rep 70: 1097-1100, 1986.

29. Curtin JP, Blessin JA, Webster KD, Rose PG, Mayer AR, Fowler WC Jr, Malfetano JH and Aivares RD: Paclitaxel, an active agent in non-squamous carcinomas of the uterine cervix: a Gynecologic Oncology Group Study. J Clin Oncol 17: 761-766, 1999. 